Research article

\title{
Effects of leaf mulch application of Acacia crassicarpa Benth., Albizia adianthifolia (Schum.) W. Wight and Albizia zygia (DC.) J. F. Macbr. on soil properties
}

\author{
F. E. Adesuyi*, C. I. Arinzechi, F. O. Iyagin, B. E. Omomoh,
} A. S. Akinbowale and H. B. Dafiewhare

Department of Forestry and Wood Technology, Federal University of Technology Akure, P.M.B 704, Ondo State, Akure, Nigeria

*Corresponding Author: adesuyifisola5@gmail.com

[Accepted: 20 December 2018]

\begin{abstract}
This study was conducted to assess soil nutrient changes following application of mulch materials from Acacia crassicarpa, Albizia zygia, and Albizia adianthifolia. Complete Randomized Design was used for experimental layout. The mulch materials constituted the treatments. The experimental plot $(3 \mathrm{~m} \times 4 \mathrm{~m})$ was partitioned into 12 micro-plots of $1 \mathrm{~m} \times 1 \mathrm{~m}$ in dimension. Adjacent micro-plots were separated from each other by a buffer $0.5 \mathrm{~m}$ wide. Each treatment including a control (without mulch) was replicated three times and treatments were randomly allocated to the micro-plots. Ambient and soil temperatures were measured daily for six weeks following treatment application. Soil samples were collected from soil depth of 0 to $15 \mathrm{~cm}$ after six weeks of mulch applications in both mulched and control plots and analyzed for $\mathrm{pH}, \%$ of Organic matter, \% of Nitrogen $(\mathrm{N})$, available Phosphorus and exchangeable cations. The study revealed that the mean levels of the various nutrients were not significantly different. The analysis showed that the application of the various mulch materials tends to reduce the temperature in hot weather condition and also temperature had a very important role to play in the decomposition process. In low-temperature condition decomposition tends to be slow while in high-temperature decomposition becomes fast.
\end{abstract}

Keywords: Soil nutrient - Soil temperature - Mulch - Decomposition - Exchangeable cations.

[Cite as: Adesuyi FE, Arinzechi CI, Iyagin FO, Omomoh BE, Akinbowale AS \& Dafiewhare HB (2018) Effects of leaf mulch application of Acacia crassicarpa Benth., Albizia adianthifolia (Schum.) W. Wight and Albizia zygia (DC.) J. F. Macbr. on soil properties. Tropical Plant Research 5(3): 370-374]

\section{INTRODUCTION}

Intensive soil cultivation has worldwide resulted in the degradation of agricultural soils, with decreases in soil organic matter and loss of soil structure, adversely affecting soil functioning and causing a long-term threat to future yields Pagliai et al. (2004). Moreover, intensive tillage operations over a long period cause a detrimental effect on surface soil as well as hastening the decomposition of soil organic matter Slentel et al. (2007). Tillage degrades the fertility of soils, limits the availability of air and water, intensifies drought stress, consumes fuel and contributes to global warming.

Agroforestry is a land use system which involves deliberate integration of trees and crop components on the same piece of land. One of the key acceptance of agroforestry is that trees enrich soil fertility and also the major recognized avenue of soil fertility improvement in tropical agroforestry is the recycling of nutrients through decomposition of tree biomass mainly litterfall or pruning, but also root that is added to the soil. Obviously, the extent of benefits derived will depend on the quantity and nutrient content of the biomass added, and the rate at which it decomposes. Soil mulching with organic material is one method of soil water protection and also helps maintain a constant soil temperature within the root system of crops (Awal \& Khan 2000, Sinkevičienè et al. 2009, Samaila et al. 2011).

Acacia crassicarpa Benth. is a fast-growing tropical tree that grows on a wide variety of soil types. It fixes nitrogen and tolerates fire, weed competition, and low soil fertility. It has recently been introduced in several 
countries of Southeast Asia and Africa, and it has proved to be one of the most promising new exotic plantation species for degraded lands (Turnbull 1987, Boland 1989, Turnbull 1991, Awang \& Taylor 1992, Awang \& Taylor 1993). Many materials have been published which states that Albizia species can be used to improve soil fertility. Albizia zygia (DC.) J. F. Macbr. and Albizia adianthifolia (Schum.) W. Wight have been stated to improve the soil organic matter, exchange calcium, magnesium, cation exchange capacity and available phosphorous of soil under its canopy in Cameroon (Prinz 1986).

Organic farming is the alternate method to reduce the cost of fertilizer and also improve the soil. Leaf biomass is a very important organic source of soil fertility improvement. The amount of $\mathrm{N}$ availability for plant uptake is influenced by decomposition of leaf litters. Leaf litter supplies the nutrient necessary for plants such as organic carbon, nitrogen, phosphorus, potassium and other nutrients in soil which are further considered as important indicators of soil productivity and the ecosystem health. Acacia crassicarpa Benth., Albizia zygia, Albizia adianthifolia can help to replace soil organic matter and nutrient status by protecting the soil against soil erosion, enhancing humus and nutrient accumulation in the soil through litter fall, mineralization and by recycling nutrients leached into the sub-soil back to topsoil. Thus, there is a need to determine soil nutrient changes following application of mulch materials from the tree species.

The soil is continuously depleting as a result of numerous human activities mostly continuous cultivation of land. This has been a serious problem that needs to be addressed. Hence a change to natural soil nutrient replenishing through litterfall. There is also an increase in the use of inorganic fertilizers which on the long run affects the yield of crops and quality of soil nutrient. To recover the lost soil nutrient, there must be a mechanism that can effectively return nutrients (soil carbon, nitrogen) to the soil in proportion to the quantity they have taken up. To contribute to this research gap, the effect of the application of leaf biomass of Acacia crassicarpa, Albizia zygia, and Albizia adianthifolia on soil temperature and the effects of the various mulch materials on soil organic matter were examined.

\section{MATERIALS AND METHOD}

Study area

The experiment was carried out at the Agroforestry Site of the Teaching and Research Farm, Federal University Of Technology Akure, Nigeria (latitude $7^{\circ} 17^{\prime} \mathrm{N}$, longitude $5^{\circ} 10^{\prime} \mathrm{E}, 350 \mathrm{~m}$ above sea level). The bimodal rainfall pattern of the area has an annual mean of $1500 \mathrm{~mm}$ and a mean annual temperature of $26^{\circ} \mathrm{C}$. The area has a bimodal rainfall pattern with an annual mean of $1500 \mathrm{~mm}$ and a mean annual temperature of $26^{\circ} \mathrm{C}$. The main growing season is from August to October, followed by a long dry season from November to April.

\section{Experimental Design}

Complete Randomized Design was used for experimental layout. The mulch materials constituted the treatments. The whole experiment plot $(3 \mathrm{~m} \times 4 \mathrm{~m})$ was partitioned into 12 micro-plots of $1 \mathrm{mx} 1 \mathrm{~m}$ in dimension. Adjacent micro-plots were separated from each other by a buffer $0.5 \mathrm{~m}$ wide. Each treatment including a control (without mulch) was replicated three times and treatments were randomly allocated to the micro-plots.

The following plant materials which have different physical and chemical characteristics were chosen for the field study; Acacia crassicarpa, Albizia adianthifolia, Albizia zygia. Matured leaves of the species were collected as mulch materials for the study. Fresh mulch materials were applied at the rate of $1 \mathrm{~kg}$ per micro-plot.

\section{Measurement of Soil Temperature and Ambient Temperature.}

Measurement of soil and ambient temperature were done daily at 6:00 pm. Soil temperature was measured using a liquid crystal display (LCD) thermoprobe set at $10 \mathrm{~cm}$ depth and ambient temperature was measured using a digital infrared thermometer.

\section{Soil Nutrient Analysis}

Soil samples were collected from each micro plot six weeks after application of mulch. The soil samples were dried sieved and labeled accordingly. The $\mathrm{pH}$ of the soil was determined using an electronic $\mathrm{pH}$ meter. $\mathrm{pH}$ was determined by immersing the glass electrode of the $\mathrm{pH}$ meter into a partly settled suspension of soil. Walkley Black wet oxidation method was used to determine soil organic carbon. Samples for Nitrogen were digested using the micro-Kjeldahl method with selenium catalyst. The digested samples were distilled after the addition of sodium hydroxide and the ammonia thus released was determined acid-base titration. Phosphorus was determined by the molybdenum blue method. Calcium and magnesium content was determined by ethylene diamine tetra acetic acid (EDTA) titration method and expressed in $\mathrm{kg} \mathrm{mol}^{-1}$. Potassium and sodium were 
determined by flame photometer and expressed in $\mathrm{kg} \mathrm{mol}^{-1}$. The phosphorus content of the soil was also determined using a $410 \mathrm{~nm}$ wavelength spectrometer.

Statistical Analysis of Data

Graphs were used to summarize the data for the soil temperature and ambient temperature. The data obtained from the various nutrient analyses were subjected to analysis of variance (ANOVA) to determine the degree of variation among the treatments used. Follow up test was carried out using Duncan's multiple range test (DMRT) to identify means that were significantly different.

\section{RESULTS}

Effect of Mulch Type on Soil Temperature

The graphical illustrations of changes in soil temperature are presented in figure 1. During the 6 weeks period of this study, soil temperature showed fluctuation over time. For all the mulched plots the soil temperature was low compared to the plots without mulch which was high. In comparison with the ambient temperature, the mulch had an effect in moderating the soil under various treatments but the range was a little bit different with the highest soil temperature being recorded as $28^{\circ} \mathrm{C}$ and the ambient temperature was $31^{\circ} \mathrm{C}$.

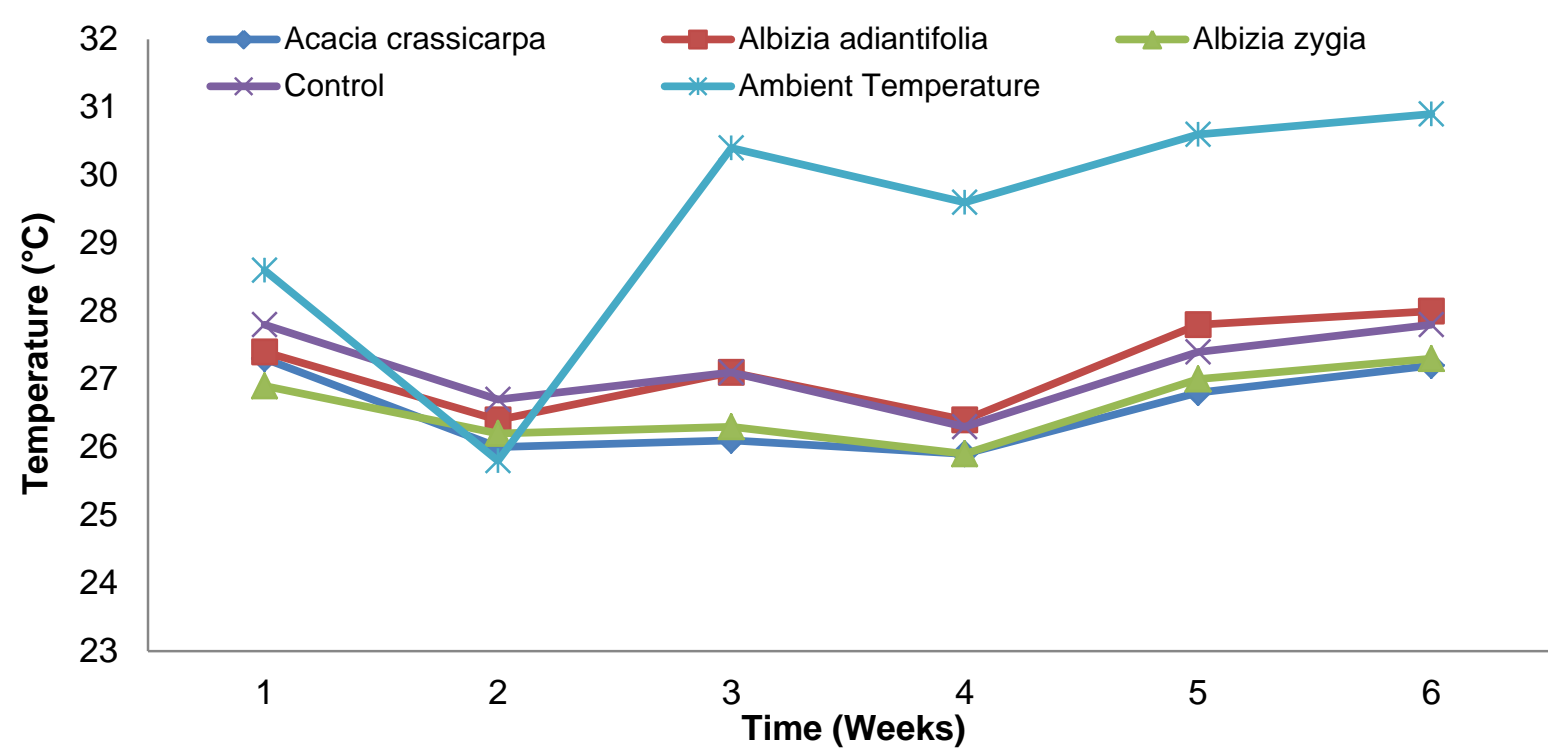

Figure 1. Effects of leaf mulch of the various species on soil temperature.

Table 1. ANOVA test of significant for soil properties of the species and control. [Sig. Value- Value of Significance]

\begin{tabular}{|c|c|c|c|c|c|c|}
\hline & Source & SS & df & MS & $\mathbf{F}$ & Sig. Value \\
\hline \multirow[t]{3}{*}{ pH } & Treatment & 0.024 & 3 & 0.008 & 0.393 & 0.761 \\
\hline & Error & 0.163 & 8 & 0.020 & & \\
\hline & Total & 0.187 & 11 & & & \\
\hline \multirow[t]{3}{*}{ OM } & Treatment & 0.014 & 3 & 0.005 & 0.541 & 0.667 \\
\hline & Error & 0.070 & 8 & 0.009 & & \\
\hline & Total & 0.085 & 11 & & & \\
\hline \multirow[t]{3}{*}{$\mathbf{C a}$} & Treatment & 6.129 & 3 & 2.043 & 0.222 & 0.879 \\
\hline & Error & 73.633 & 8 & 9.204 & & \\
\hline & Total & 79.763 & 11 & & & \\
\hline \multirow[t]{3}{*}{ Mg } & Treatment & 9.003 & 3 & 3.001 & 0.624 & 0.619 \\
\hline & Error & 38.473 & 8 & 4.809 & & \\
\hline & Total & 47.477 & 11 & & & \\
\hline \multirow[t]{3}{*}{ Phos } & Treatment & 0.752 & 3 & 0.251 & 0.173 & 0.911 \\
\hline & Error & 11.558 & 8 & 1.445 & & \\
\hline & Total & 12.310 & 11 & & & \\
\hline \multirow[t]{3}{*}{$\mathbf{K}$} & Treatment & 9.180 & 3 & 3.060 & 2.491 & 0.134 \\
\hline & Error & 9.827 & 8 & 1.228 & & \\
\hline & Total & 19.007 & 11 & & & \\
\hline \multirow[t]{3}{*}{$\mathbf{N}$} & Treatment & 0.001 & 3 & 0 & 1.326 & 0.332 \\
\hline & Error & 0.002 & 8 & 0 & & \\
\hline & Total & 0.002 & 11 & & & \\
\hline
\end{tabular}


The results of the One-way Analysis of Variance for assessing the presence of the significant difference in the soil chemical properties among species and control are represented in table 1 . The results shows that there is no significant difference $(\mathrm{p}<0.05)$ among the species except for potassium where a significant difference was discovered to exist between Albizia adianthifolia and the control.

Table 2. Comparison of soil chemical properties with Duncan multiple range test (DMRT).

\begin{tabular}{lrrrr}
\hline Soil properties & Acacia crassicarpa & Albizia adianthifolia & Albizia zygia & Control \\
\hline pH & $6.52^{\mathrm{a}} \pm 0.1$ & $6.58^{\mathrm{a}} \pm 0.3$ & $6.60^{\mathrm{a}} \pm 0.1$ & $6.50^{\mathrm{a}} \pm 0.1$ \\
Organic Matter & $1.58^{\mathrm{a}} \pm 0.1$ & $1.52^{\mathrm{a}} \pm 0.1$ & $1.48^{\mathrm{a}} \pm 0.6$ & $1.53^{\mathrm{a}} \pm 0.8$ \\
Calcium & $7.47^{\mathrm{a}} \pm 2.8$ & $9.00^{\mathrm{a}} \pm 3.6$ & $7.10^{\mathrm{a}} \pm 3.1$ & $7.73^{\mathrm{a}} \pm 2.5$ \\
Magnesium & $5.70^{\mathrm{a}} \pm 2.9$ & $3.53^{\mathrm{a}} \pm 2.2$ & $4.40^{\mathrm{a}} \pm 1.4$ & $3.63^{\mathrm{a}} \pm 1.9$ \\
Phosphorus & $3.06^{\mathrm{a}} \pm 1.6$ & $2.54^{\mathrm{a}} \pm 1.3$ & $2.39^{\mathrm{a}} \pm 1.1$ & $2.61^{\mathrm{a}} \pm 0.7$ \\
Potassium & $4.50^{\mathrm{a}} \pm 0.4$ & $5.80^{\mathrm{b}} \pm 2.0$ & $4.00^{\mathrm{ab}} \pm 0.5$ & $3.45^{\mathrm{a}} \pm 0.6$ \\
Nitrogen & $1.04^{\mathrm{a}} \pm 0.0$ & $1.03^{\mathrm{a}} \pm 0.0$ & $1.01^{\mathrm{a}} \pm 0.1$ & $1.03^{\mathrm{a}} \pm 0.0$ \\
\hline
\end{tabular}

The follow-up procedure for the mean separation indicates that values in the same row followed by the same letter(s) are not significantly different at 0.05 level of significance (Table 2). From this table, Acacia crassicarpa has the highest mean value of organic matter $\left(1.58^{\mathrm{a}} \pm 0.1\right)$, magnesium $\left(5.70^{\mathrm{a}} \pm 2.9\right)$, phosphorus $\left(3.06^{\mathrm{a}} \pm 1.6\right)$ and nitrogen $\left(1.04^{\mathrm{a}} \pm 0.0\right)$ while Albizia zygia has the lowest mean value of organic matter $\left(1.48^{\mathrm{a}} \pm 0.6\right)$, calcium $\left(7.10^{\mathrm{a}} \pm 3.1\right)$, phosphorus $\left(2.39^{\mathrm{a}} \pm 1.1\right)$ and nitrogen $\left(1.01^{\mathrm{a}} \pm 0.1\right)$.

\section{DISCUSSION}

During the six weeks period of this study, the entire measured variable (soil temperature, ambient temperature and soil nutrients) showed fluctuation with the climatic condition. This is due to certain climatic conditions such as rainfall, temperature and humidity. The highest temperature was observed in soil under Albizia adianthifolia mulch. This may be due to their fast decomposition rate and also the soil under control had a high temperature.

Soil temperature may increase with depth below the surface, which makes the surface temperature undergo fluctuation at the different time of the year due to change in climatic condition. The amount of heat energy reaching the surface of the soil and its thermal properties are factors responsible for the change in temperature (Taylor \& Parkinson 1988). The temperature of the surface layer during the sunny day may be very much different for a bare soil as compared to the one with a vegetative cover. The temperature a soil attains depends on how much heat that reaches the soil surface (Nye \& Greenland 1960). The result of the nutrient analysis showed that the nutrient level of the soil were not that affected by the various treatments. The nutrients were not significantly increased after weeks of mulch application. The reason to the nutrient not being significant maybe due to the low temperature of the season and also since decomposition is an enzyme-mediated biological process carried out by bacteria and fungi; it is very sensitive to temperature. In most soils, the decomposition rate peaks at about $25^{\circ} \mathrm{C}$ and declines as temperature varies from this maximum. A study by Swift \& Prichet (1984) showed that the rate of decomposition is usually controlled by several factors such as the physiochemical environment including climate and chemical composition of the organic matter and nature of the decomposer. Therefore change in soil nutrient content after mulch application can be attributed to the decomposition and mineralization of the mulch materials. Soil moisture also affects the activity of microorganisms. Very dry or very wet (flooded) conditions tend to reduce decomposition rates (Hanson et al. 1993).

\section{CONCLUSION}

This study has examined the effect of the application of leaf mulch of Acacia crassicarpa, Albizia adianthifolia, Albizia zygia on soil properties. These results did not support the hypothesis that the application of the various mulch materials has the significant impact on soil properties. Since the use of organic mulch affects majorly the soil temperature, which influences soil chemical, physical and biological processes. It also reduced soil temperature at the different climatic condition. Hence there is need for proper selection of mulch materials which can bring about a direct impact on the soil.

From this study, it is recommended that selection of mulch material should be based on species richness in nutrients, decomposition and mineralization rates which is necessary for basic plant nutrition.

\section{ACKNOWLEDGEMENTS}

We wish to appreciate the Department of Forestry and Wood Technology, Akure for giving us the authorization to access the Agroforestry Site of the Teaching and Research Farm, Federal University Of 
Technology Akure, Nigeria within their Jurisdictions where data was collected for this work.

\section{REFERENCES}

Awang K \& Taylor DA (1992) Tropical Acacias in East Asia and the Pacific. Proceedings of the First Meeting, Consultative Group for Research and Development of Acacias (COGREDA), Phuket, Thailand, Winrock International Institute for Agricultural Research, 105 p.

Awal MA \& Khan MAH (2000) Mulch induced ecophysiological growth and yield of maize. Pakistan Journal of Biological Sciences 3: 61-64.

Awang K \& Taylor DA (1993) Acacias for rural, industrial and environmental development. Proceedings, Second Meeting, Consultative Group for Research and Development of Acacias (COGREDA), Udorn Thani, Thailand, Winrock International Institute for Agricultural Research and FAO, 258 p.

Boland DJ (1989) Trees for the Tropics. Growing Australian multipurpose trees and shrubs in developing countries. ACIAR Monograph No. 10, Canberra, Australia.

Hanson PJ, Wullschleger SD, Bohlman SA \& Todd. DE (1993) Seasonal and topographic patterns of forest floor $\mathrm{CO}_{2}$ efflux from an upland oak forest. Tree Physiology 13: 1-15.

Nye PA \& Greenland DJ (1960) Soil under shifting cultivation. Technical communication 51, Farmharm, Common Wealth Bureau of Soils, pp. 147.

Pagliai M, Vignozzi N \& Pellegrini S (2004) Soil structure and the effect of management practices. Soil and Tillage Research 79: 131-143.

Prinz D (1986) Ecosystem fertility and fallow function Agroforestry system. Journal of diary science 86: 40704078.

Samaila AA, Amans EB, Abubakar IU, Babaji B (2011) Yield and fruit quality of tomato (Lycopersicon esculentum Mill) as influenced by mulching, nitrogen and irrigation interval. International Research Journal of Agricultural Science and Soil Science 1(3): 90-95.

Sinkevičienė A, Jodaugienė D, Pupalienė R \& Urbonienè M (2009) The influence of organic mulches on soil properties and crop yield. Agronomy Research 7(1): 485-491.

Slentel I, Rogasik J, Funder U \& Panten K( 2007) Effect of tillage system and P fertilization on soil physical and chemical properties, crop yield and nutrient uptake. Soil and Tillage Research 32(2): 50-57.

Swift M J \& Prichet T S (1984) Tropical Soil Biology and Fertility (TSBF): planning for research biology international special size 9: 24.

Taylor BR \& Parkinson D (1988) Aspen and Pine leaf litter decomposition in laboratory microorganism interaction of temperature and moisture level. Journal of Botany, 66(10): 1966-1973.

Turnbull JV (1987) Australian acacias in developing countries. Proceedings of an international workshop held at the Forestry Training Centre, Gympie, Qld., Australia, ACIAR proceedings No. 16, 196 p.

Turnbull JV (1991) Advances in Tropical Acacia research. International workshop, Bangkok, Thailand, ACIAR proceedings No. 35, $234 \mathrm{p}$. 